\title{
Influence of Plant Spacing and Number of Seedlings/hill on Yield, Its Components and Some Grain Quality Characters for Three Egyptian Rice Cultivars
}

\author{
Doaa A. Abd ElBary ${ }^{1}$, Khaled M.H. Abd El Salam ${ }^{1}$ and Ahmed M. Shaalan ${ }^{2}$
}

\begin{abstract}
Two field experiments were conducted at the Agricultural Research Station, Alexandria University, during 2017and 2018 summer seasons to evaluate the response of three rice cultivars (Giza 179, Sakha 106 and Giza 178) to different plant spacing $(15 \times 20,20 \times 20$ and $20 \times 25 \mathrm{~cm})$ and number of seedlings/hill (2, 3 and 4 seedlings/hill). A split split plot design with three replicates was used in both seasons. Comparison between means showed that rice cultivar Giza 178 gave the highest values for number of panicles $/ \mathrm{m}^{2}$, number of filled grains/ panicle, amylose $\%$ and protein $\%$ in both study seasons. Furthermore, for 1000-grain weight, grain yield and broken \% characters, Giza 179 cultivar gave the highest values for such characters in both seasons. Sakha 106 showed superiority in hulling $\%$ and milling $\%$ in both seasons. The highest values for number of panicles $/ \mathbf{m}^{2}$, number of filled grains/panicle, grain yield, hulling \%, milling $\%$ and protein $\%$ in both seasons were noticed by transplanting rice at $20 \times \frac{20}{\mathrm{~cm}}$ plant spacing. Furthermore, for 1000-grain weight, broken $\%$ and amylose \% characters, transplanting at $20 \times 25 \mathrm{~cm}$ gave the highest values for such characters in both seasons. Three seedlings/hill showed the highest values for number of panicles $/ \mathrm{m}^{2}$, number of filled grains/panicle, 1000-grain weight, grain yield, hulling $\%$, milling $\%$ and protein $\%$ in both seasons. Interaction between cultivars and plant spacing showed that Giza 179 rice cultivar and $15 \times 20 \mathrm{~cm}$ plant spacing showed the highest values for grain yield in both seasons. Moreover, Giza 178 and four seedlings/hill showed highest number of filled grains/panicle and protein $\%$ in 2017 season only while, highest amylose \% in 2018 season only. Transplanting rice at $20 \times 20 \mathrm{~cm}$ plant spacing and 3 seedlings/hill showed superior values for grain yield and milling \% in 2017 only, while it recorded the highest values for number of filled grains/panicle and 1000-grain weight in 2018 season only. Sakha 106 rice cultivar sown at $20 \times 20 \mathrm{~cm}$ plant spacing and 3 seedlings/hill showed superiority for hulling $\%$ in both seasons, respectively and superiority for number of panicles/ $\mathrm{m}^{2}$ in 2017 season only. Moreover, the highest value for number of panicles $/ \mathrm{m}^{2}$ in 2018 was recorded with Giza 178 rice cultivar sown at $20 x$ $20 \mathrm{~cm}$ plant spacing and 3 seedlings/hill.
\end{abstract}

Keywords: Rice, plant density, cultivars, number of seedlings, yield and quality.

\section{INTRODUCTION}

Rice (Oryza sativa L.) is one of the major staples foods, feeding more than half of the world's population. It is grown in more than 100 countries, predominantly in Asia (Depar et al., 2011) and provides 21\% and 15\% per capita of dietary energy and protein, respectively (Maclean et al., 2002).

Rice productivity is a function of the proper cultural practices through the life period of the rice plant. Selection of the suitable genotype and adequate population density play an important role in maximizing production. The world population is expected to reach 8 billion by 2030 and therefore, rice production must be increased by $50 \%$ in order to meet the growing demand (Rafii, 2014).Rice is the only cereal crop cooked and consumed mainly as whole grains, and quality considerations are much more important than for any other food crop (Hossain et al., 2009).

El-Shayieb (2003) confirmed that narrow spacing of $10 \times 20 \mathrm{~cm}$ gave the highest grain yield and yield components of Giza 177 rice cultivar (inbred rice) as compared with $20 \times 20$ or $30 \times 20 \mathrm{~cm}$. Gorgy (2007) indicated that $20 \times 20 \mathrm{~cm}$ spacing gave the highest plant height., leaf area index (LAI), panicle weight, number of filled grains/panicle, number of panicles/hill and grain yield for Sk2047H (hybrid) and Giza178 (inbred rice).

Yield increasing is achieved by the high ratio of grain-leaf, high leaf area index(LAI), more photosynthetic substance accumulation, high grain weight and harvest index, and the formation of high quality population; great dry matter accumulation at the late growth stage, high crop growth rate (CGR) and net assimilation rate (NAR), strong production capacity of photosynthetic substance, reasonable output and transmission of substances in stem-sheath, higher number of effective panicles and high 1000-grain weight which result in high grain yield (Liming et al., 2015).

Hasanuzzaman et al., 2009 reported that plant spacing and no. of seedlings/ hill showed a significant effect on tillering and dry matter yield of transplanted rice. At initial stages, the treatments did not show any significant effect. At all growth stages, wider row

\footnotetext{
${ }^{1}$ Research Institute, Agricultural Research Center, Alexandria, Egypt. 2-Faculty of Desert and Environmental Agriculture, Matrouh University. Received December 01, 2018, Accepted December 25, 2018
} 
spacings $(25 \mathrm{~cm} \times 20 \mathrm{~cm})$ and higher no. of seedlings per hill ( 3 and 4) showed maximum tillering. Closer plant spacing reduced the number of effective tillers and increased the tiller mortality. Wider spacing coupled with higher no. of seedlings hill (4 seedlings) accumulated maximum amount of dry matter, but transplanting more than 2 seedlings per hill did not show significantly higher results. Productivity of tillers as well as dry matter yield was lower with closer spacing and transplanting single seedlings hill. Plant height, panicle grain weight, 1000-grain weight, harvest index, hulling\%, milling\% and head rice\% were not significantly affected by hill spacing. Number of tillers/hill, plant dry weight/hill, chlorophyll content, panicle length, number of filled grains/panicle and grain yield significantly increased with increasing space between hills from $15 \times 10$ to $15 \times 20 \mathrm{~cm}$. On the contrary, number of tillers $/ \mathrm{m}^{2}$ significantly decreased with increasing space between hills (Abd El Salam, 2003).

Kengo and Kitano (2005) studied the effect of 5 different number of seedlings/hill $(1,3,5,7$ and 9 seedlings/hill) on tillering time, tillering production and number of spikelets/panicle. They indicated that increasing number of seedlings/hill from 1 to 9 seedlings significantly increased tillering time and tillering production, while, decreased number of spikelets/panicle. Showed that the highest values for yield and yield components characters were obtained by transplanting at $20 \times 20 \mathrm{~cm}$ hill spacing and using 7 seedlings/hill. Also, milling characters, amylose and gel consistency didn't show any significant effect with both factors. Dass et al. (2016) studied the effect of two plant spacings $20 \times 20$ and $25 \times 25 \mathrm{~cm}$ and they found that wider plant spacing $(25 \times 25 \mathrm{~cm})$ resulted in generally and significantly higher grain yield and root- shoot ratio.

This study aimed to investigate the performance of three rice cultivars under different hill spacings and different number of seedlings/hill and their interactions in relation to yield and yield components and grain quality characters.

\section{MATERIALS AND METHODS}

Two field experiments were conducted at the Agricultural Research Experiment Station, Faculty of Agriculture, Alexandria University, during the two summer seasons, 2017and 2018 to evaluate the response of three rice cultivars (Giza 179, Sakha 106 and Giza $178)$ to different plant spacings $(15 \times 20,20 \times 20$ and 20 $\mathrm{x} 25 \mathrm{~cm})$ and three number of seedlings/hill $(2,3$ and 4 seedlings/hill). The experimental site soil had the following properties: $\mathrm{pH}=8.1$, total organic matter= $1.3 \%$, available $\mathrm{N}=37.0 \mathrm{ppm}$, available $\mathrm{P}=11.0 \mathrm{ppm}$ and available $\mathrm{K}=615.0 \mathrm{ppm}$.
A split split plot design with three replicates was used in both seasons. The main plots were devoted to the three rice cultivars while, different plant spacings were applied in the sub-plots and the three number of seedlings/hill were applied to sub-sub plots. The previous crop was wheat in the two seasons. Sub-sub plot size was $10 \mathrm{~m}^{2}$. Sowing date in nursery was 10 May and plants were transplanted after 30 days from sowing to permanent field, in both seasons.

At harvest, one meter square was harvested for determination of grain yield (GY) per plot then it was converted to tons/fed. Also, number of panicles $/ \mathrm{m}^{2}$, number of filled grains/panicle and 1000-grain weight (g) were determined. Furthermore, grain quality characters such as hulling, milling, broken, protein and amylose percentages were recorded according to International Rice Research Institute (IRRI 1996). Analysis of variance was carried out according to Gomez and Gomez (1984) using SAS program, version 8.0.

\section{RESULTS AND DISCUSSION}

\section{Effect of rice cultivars:}

Performance of the studied rice cultivars, in both seasons, is presented in tables (1 and 2). Data revealed that there were significant differences between rice cultivars for all studied characters, except number of panicles/ $\mathrm{m}^{2}$ in 2017 season.

Comparison between means showed that rice cultivar Giza 178 gave the highest values for number of panicles $/ \mathrm{m}^{2}$ (342.9), number of filled grains (126.79), amylose \% (19.38 \%) and protein \% (8.01\%), as average values in the two seasons, respectively. Furthermore, for 1000-grain weight, grain yield and broken \% characters, Giza 179 rice cultivar gave the highest values for such characters and their average values over the two seasons were $26.32 \mathrm{gm}, 3.92 \mathrm{t} / \mathrm{fed}$ and $11.91 \%$, respectively. Sakha 106 showed superiority in hulling $\%$ and milling $\%$ and their average values over the two seasons were $80.29 \%$ and $70.83 \%$, respectively. These findings were similar to those reported by El-Sherif et al. (2007), El-Nory (2008), Radwan et al. (2008), Rebeira et al. (2014) and Abd El Salam et al. (2016) who recorded variations between rice cultivars for agronomic and quality characters, and that could be attributed to genetic variations, between cultivars and their response to environmental conditions.

\section{Effect of hill spacings:}

One of the goals of the present study was to determine the optimum plant spacing for obtaining higher yield and quality by reducing competition between plants. The data presented in tables (1 and 2) showed that transplanting at $20 \times 20 \mathrm{~cm}$ significantly 
affected most studied characters in both seasons and gave the highest values for number of panicles $/ \mathrm{m}^{2}$ (342.10), number of filled grains/panicle (121.61), grain yield (3.83 t/fed), hulling \% (79.92\%), milling \% (70.68 $\%)$ and protein $\%(7.99 \%)$, as average values for both seasons. Furthermore, for 1000-grain weight, broken $\%$ and amylose $\%$ characters, transplanting at $20 \times 25 \mathrm{~cm}$ the gave highest values for such characters and their average values for both seasons were $24.90 \mathrm{gm}, 8.85 \%$ and $19.35 \%$, respectively. The increase in 1000-grain weight at wider spacing may be due to more light penetration leading to higher photosynthetic rate and photo assimilates production which was expressed in higher grain filling and heavier grains. These findings were similar to those reported by Abd El Salam (2006), Shaalan (2009), Liming et al. (2015) and Das et al. (2016).

\section{Effect of number of seedlings/ hill:}

Number of seedlings/hill significantly affected all studied characters in both seasons as shown in tables

(1 and 2). Transplanting rice using three seedlings/hill showed the highest values for most studied characters in both seasons. The highest values for number of panicles $/ \mathrm{m}^{2}$ (345.20), number of filled grains/panicle (120.56), 1000 grain weight (25.17 gm), grain yield
(3.94 t/fed), hulling \% (79.84 \%), milling \% (70.71\%) and protein $\%(8.03 \%)$, as average values for the two seasons. Moreover, the highest average value for both seasons for broken \% (8.57 \%) was obtained by transplanting two seedlings/hill. Furthermore, the highest average value for amylose \% (19.36) was recognized with 4 seedlings/hill. These findings are similar to those reported by Kengo and Kitano (2005) and Abd El Salam (2006).

\section{Interaction between cultivars and plant spacings:}

Interaction between cultivars and plant spacings showed significant effect on most of the studied characters, especially in 2017 season. Giza 179 rice cultivar and $15 \times 20 \mathrm{~cm}$ plant spacing showed the highest values for grain yield (3.96 and $4.24 \mathrm{t} / \mathrm{fed}$ ) in two successive seasons, respectively, while it showed the highest value for milling \% (71.10\%) in 2017 season only, as shown in tables ( 3 and 4). Moreover, the highest values for number of filled grains/panicle (134.89 and 149.2) were noticed by using Giza 178 rice cultivar and $20 \times 20 \mathrm{~cm}$ plant spacing. Furthermore, Giza 179 and 20 x $25 \mathrm{~cm}$ showed superiority in 1000grain weight (26.52 and $27.26 \mathrm{gm})$ in the first and second seasons, respectively.

Table 1. Mean values for No. of panicles $/ \mathrm{m}^{2}$, No. of filled grains/ panicles, 1000 -grain weight (g) and grain yield (tons/fed) as affected by cultivars, hill spacings and no. of seedlings/hill in 2017 and 2018 seasons

\begin{tabular}{|c|c|c|c|c|c|c|c|c|}
\hline \multirow{2}{*}{ Treatment } & \multicolumn{2}{|c|}{ No. of panicles $/ \mathrm{m}^{2}$} & \multicolumn{2}{|c|}{$\begin{array}{l}\text { No. filled grains/ } \\
\text { panicle }\end{array}$} & \multicolumn{2}{|c|}{ 1000-grain weight (g) } & \multicolumn{2}{|c|}{ Grain yield (tons/fed) } \\
\hline & 2017 & 2018 & 2017 & 2018 & 2017 & 2018 & 2017 & 2018 \\
\hline \multicolumn{9}{|l|}{ Cultivars } \\
\hline G. 179 & 315.10 & 323.30 & 99.30 & 118.80 & 25.92 & 26.73 & 3.83 & 4.02 \\
\hline S. 106 & 317.70 & 343.70 & 111.19 & 119.40 & 24.79 & 24.97 & 3.63 & 3.44 \\
\hline G.178 & 328.80 & 357.00 & 124.59 & 129.00 & 22.72 & 23.33 & 3.50 & 3.81 \\
\hline LSD $_{0.05}$ & NS & 18.23 & 8.18 & 7.13 & 0.69 & 0.77 & 0.09 & 0.16 \\
\hline \multicolumn{9}{|c|}{ Hill Spacings (cm) } \\
\hline $15 * 20$ & 319.30 & 338.30 & 107.00 & 122.10 & 24.06 & 24.86 & 3.65 & 3.69 \\
\hline $20 * 20$ & 332.30 & 351.90 & 115.63 & 127.60 & 24.55 & 25.18 & 3.76 & 3.91 \\
\hline $20 * 25$ & 309.90 & 333.90 & 112.44 & 117.40 & 24.83 & 24.99 & 3.54 & 3.68 \\
\hline $\mathbf{L S D}_{0.05}$ & 7.89 & 10.18 & 4.54 & 5.40 & 0.25 & 0.20 & 0.06 & 0.05 \\
\hline \multicolumn{9}{|c|}{ No. of Seedlings } \\
\hline 2 & 305.50 & 323.90 & 106.81 & 118.60 & 23.89 & 24.48 & 3.42 & 3.48 \\
\hline 3 & 334.00 & 356.40 & 115.22 & 125.90 & 24.95 & 25.40 & 3.86 & 4.04 \\
\hline 4 & 322.10 & 343.80 & 113.04 & 122.60 & 24.59 & 25.15 & 3.69 & 3.76 \\
\hline LSD $_{0.05}$ & 6.98 & 6.50 & 3.90 & 5.08 & 0.32 & 0.31 & 0.07 & 0.06 \\
\hline
\end{tabular}

N.S: Not significant 
Table 2. Mean values for hulling, milling, broken, amylose and protein percentages as affected by cultivars, hill spacings and no. of seedlings in 2017 and 2018 seasons

\begin{tabular}{lcccccccccc}
\hline \multirow{2}{*}{ Treatment } & \multicolumn{2}{c}{ Hulling \% } & \multicolumn{2}{c}{ Milling \% } & \multicolumn{2}{c}{ Broken \% } & \multicolumn{2}{c}{ Amylose \% } & \multicolumn{2}{c}{ Protein \% } \\
\cline { 2 - 12 } & $\mathbf{2 0 1 7}$ & $\mathbf{2 0 1 8}$ & $\mathbf{2 0 1 7}$ & $\mathbf{2 0 1 8}$ & $\mathbf{2 0 1 7}$ & $\mathbf{2 0 1 8}$ & $\mathbf{2 0 1 7}$ & $\mathbf{2 0 1 8}$ & $\mathbf{2 0 1 7}$ & $\mathbf{2 0 1 8}$ \\
\hline Cultivars & & & & & & & & & & \\
G. 179 & 79.61 & 79.06 & 70.64 & 70.90 & 11.74 & 12.09 & 19.28 & 19.39 & 7.69 & 7.99 \\
S. 106 & 79.99 & 80.58 & 70.65 & 71.02 & 5.31 & 6.07 & 19.00 & 18.93 & 7.74 & 8.13 \\
G.178 & 79.54 & 79.67 & 69.81 & 70.54 & 7.46 & 8.28 & 19.42 & 19.34 & 7.93 & 8.10 \\
\hline LSD 0.05 & $\mathbf{0 . 2 5}$ & $\mathbf{0 . 1 6}$ & $\mathbf{0 . 0 8}$ & $\mathbf{0 . 2 7}$ & $\mathbf{0 . 0 9}$ & $\mathbf{0 . 0 5}$ & $\mathbf{0 . 1 3}$ & $\mathbf{0 . 3 1}$ & $\mathbf{0 . 1 3}$ & $\mathbf{0 . 1 0}$ \\
\hline Hill Spacings (cm) & & & & & & & & & & \\
\hline 15*20 & 79.66 & 79.91 & 70.39 & 70.87 & 7.89 & 8.38 & 18.91 & 19.37 & 7.75 & 8.07 \\
$\mathbf{2 0} * \mathbf{2 0}$ & 79.94 & 79.89 & 70.50 & 70.86 & 8.14 & 8.79 & 19.23 & 19.25 & 7.87 & 8.11 \\
$\mathbf{2 0} * \mathbf{2 5}$ & 79.52 & 79.49 & 70.21 & 70.71 & 8.45 & 9.25 & 19.55 & 19.02 & 7.73 & 8.05 \\
\hline LSD 0.05 & $\mathbf{0 . 0 9}$ & $\mathbf{0 . 1 3}$ & $\mathbf{0 . 0 8}$ & $\mathbf{N S}$ & $\mathbf{0 . 1 1}$ & $\mathbf{0 . 1 1}$ & $\mathbf{0 . 1 0}$ & $\mathbf{0 . 1 1}$ & $\mathbf{0 . 1 0}$ & NS \\
\hline No. of Seedlings & & & & & & & & & & 7.98 \\
\hline $\mathbf{2}$ & 79.60 & 79.64 & 70.20 & 70.89 & 8.22 & 8.92 & 19.06 & 19.06 & 7.58 & 7.98 \\
3 & 79.82 & 79.87 & 70.57 & 70.86 & 8.09 & 8.66 & 19.24 & 19.25 & 7.90 & 8.15 \\
4 & 79.71 & 79.79 & 70.32 & 70.70 & 8.18 & 8.83 & 19.38 & 19.33 & 7.87 & 8.10 \\
\hline LSD 0.05 & $\mathbf{0 . 1 0}$ & $\mathbf{0 . 1 2}$ & $\mathbf{0 . 0 9}$ & $\mathbf{0 . 1 2}$ & $\mathbf{0 . 1 3}$ & $\mathbf{0 . 1 3}$ & $\mathbf{0 . 1 4}$ & $\mathbf{0 . 1 9}$ & $\mathbf{0 . 0 8}$ & $\mathbf{0 . 0 9}$ \\
\hline
\end{tabular}

N.S: Not significant

Table 3. Mean values for some characters as affected by the interaction between rice cultivars, hill spacings in 2017 season

\begin{tabular}{|c|c|c|c|c|c|c|}
\hline \multirow{2}{*}{$\begin{array}{ll}\text { Cultivars } & \text { Hill spacings }\end{array}$} & \multicolumn{3}{|c|}{ No. filled grains/ panicle } & \multicolumn{3}{|c|}{ 1000-grain weight $(\mathrm{g})$} \\
\hline & $15 * 20$ & $20 * 20$ & $20 * 25$ & $15 * 20$ & $20 * 20$ & $20 * 25$ \\
\hline G. 179 & 105.33 & 96.11 & 96.44 & 25.94 & 25.30 & 26.52 \\
\hline S. 106 & 105.56 & 115.89 & 112.11 & 23.97 & 25.36 & 25.03 \\
\hline G.178 & 110.11 & 134.89 & 128.78 & 22.27 & 22.97 & 22.92 \\
\hline \multirow[t]{3}{*}{ LSD 0.05} & & 9.08 & & \multicolumn{3}{|c|}{0.69} \\
\hline & \multicolumn{3}{|c|}{$\begin{array}{c}9.08 \\
\text { Grain yield (tons/ fed) }\end{array}$} & & lling (\% & \\
\hline & $15 * 20$ & $20 * 20$ & $20 * 25$ & $15 * 20$ & $20 * 20$ & $20 * 25$ \\
\hline G. 179 & 3.96 & 3.83 & 3.69 & 71.10 & 70.60 & 70.22 \\
\hline S. 106 & 3.58 & 3.81 & 3.49 & 70.50 & 70.86 & 70.58 \\
\hline G.178 & 3.42 & 3.63 & 3.44 & 69.56 & 70.03 & 69.82 \\
\hline \multirow{2}{*}{ LSD 0.05} & \multicolumn{3}{|c|}{0.11} & \multicolumn{3}{|c|}{0.13} \\
\hline & \multicolumn{3}{|c|}{ Broken (\%) } & \multicolumn{3}{|c|}{ Protein $(\%)$} \\
\hline G. 179 & 11.08 & 11.86 & 12.25 & 7.84 & 7.74 & 7.50 \\
\hline S. 106 & 5.19 & 5.17 & 5.54 & 7.64 & 7.92 & 7.66 \\
\hline G.178 & 7.41 & 7.40 & 7.56 & 7.78 & 7.96 & 8.05 \\
\hline LSD 0.05 & \multicolumn{3}{|c|}{0.16} & \multicolumn{3}{|c|}{0.16} \\
\hline
\end{tabular}

Table 4. Mean values for some characters as affected by the interaction between rice cultivars and hill spacing in 2018 season

\begin{tabular}{cccccccc}
\hline \multirow{2}{*}{ Hill spacings } & \multicolumn{3}{c}{ No. filled grains/ panicle } & \multicolumn{3}{c}{$\mathbf{1 0 0 0}$-grain weight (g) } \\
\cline { 3 - 8 } Cultivars & $\mathbf{1 5} * \mathbf{2 0}$ & $\mathbf{2 0} * \mathbf{2 0}$ & $\mathbf{2 0} * \mathbf{2 5}$ & $\mathbf{1 5} * \mathbf{2 0}$ & $\mathbf{2 0} * \mathbf{2 0}$ & $\mathbf{2 0} * \mathbf{2 5}$ \\
\hline G. 179 & 124.40 & 114.00 & 117.90 & 26.72 & 26.18 & 27.26 \\
S. 106 & 117.80 & 119.70 & 120.70 & 24.89 & 25.67 & 24.33 \\
G.178 & 124.10 & 149.20 & 113.60 & 22.96 & 23.66 & 23.37 \\
\hline LSD 0.05 & \multicolumn{3}{c}{$\mathbf{9 . 2 5}$} \\
\hline Grain yield (tons/ fed) & \multicolumn{3}{c}{ Amylose (\%) } \\
\hline G. 179 & 4.24 & 3.98 & 3.84 & 19.39 & 19.44 & 19.33 \\
S. 106 & 3.19 & 3.71 & 3.40 & 19.14 & 18.88 & 18.75 \\
G.178 & 3.62 & 4.03 & 3.78 & 19.59 & 19.44 & 18.97 \\
\hline LSD 0.05 & \multicolumn{3}{c}{$\mathbf{0 . 1 6}$} \\
\hline
\end{tabular}



Table 5. Mean values for some characters as affected by the interaction between rice cultivars and no. of seedlings in 2017 and 2018 seasons

\begin{tabular}{|c|c|c|c|c|c|c|c|c|c|c|c|c|c|c|c|c|c|c|c|c|c|}
\hline \multirow{2}{*}{ Cultivars } & \multicolumn{3}{|c|}{ No. filled grains/ panicle 2017} & \multicolumn{3}{|c|}{$\begin{array}{c}\text { Grain yield } \\
\text { (tons/ fed) } 2017\end{array}$} & \multicolumn{3}{|c|}{$\begin{array}{c}\text { Grain yield } \\
\text { (tons/ fed) } 2018 \\
\end{array}$} & \multicolumn{3}{|c|}{ Milling (\%) 2017} & \multicolumn{3}{|c|}{ Broken (\%) 2017} & \multicolumn{3}{|c|}{ Amylose (\%) 2018} & \multicolumn{3}{|c|}{ Protein (\%) 2017} \\
\hline & 2 & 3 & 4 & 2 & 3 & 4 & 2 & 3 & 4 & 2 & 3 & 4 & 2 & 3 & 4 & 2 & 3 & 4 & 2 & 3 & 4 \\
\hline G. 179 & 89.44 & 106.67 & 101.78 & 3.32 & 4.22 & 3.95 & 3.49 & 4.50 & 4.14 & 70.44 & 71.02 & 70.48 & 11.91 & 11.59 & 11.71 & 19.24 & 19.44 & 19.50 & 7.28 & 7.88 & 7.93 \\
\hline S. 106 & 109.56 & 113.44 & 110.56 & 3.55 & 3.73 & 3.61 & 3.25 & 3.74 & 3.32 & 70.57 & 70.72 & 70.70 & 5.36 & 5.29 & 5.26 & 19.00 & 18.87 & 18.92 & 7.70 & 7.88 & 7.66 \\
\hline G.178 & 121.44 & 125.56 & 126.78 & 3.38 & 3.62 & 3.50 & 3.69 & 3.93 & 3.82 & 69.62 & 69.99 & 69.81 & 7.41 & 7.41 & 7.57 & 18.95 & 19.46 & 19.60 & 7.78 & 7.98 & 8.04 \\
\hline LSD 0.05 & \multicolumn{3}{|c|}{8.69} & \multicolumn{3}{|c|}{0.12} & \multicolumn{3}{|c|}{0.16} & \multicolumn{3}{|c|}{0.14} & \multicolumn{3}{|c|}{0.11} & \multicolumn{3}{|c|}{0.36} & \multicolumn{3}{|c|}{0.15} \\
\hline
\end{tabular}

Table 6. Mean values for some characters as affected by the interaction between hill spacings and no. of seedlings in 2017 and 2018 seasons

\begin{tabular}{|c|c|c|c|c|c|c|c|c|c|c|c|c|c|c|c|c|c|c|}
\hline Cultivars & \multicolumn{3}{|c|}{ No. of panicles 2017} & \multicolumn{3}{|c|}{$\begin{array}{l}\text { No. filled grains/ } \\
\text { panicle } 2018\end{array}$} & \multicolumn{3}{|c|}{$\begin{array}{l}\text { 1000-grain weight } \\
\text { (g) } 2018\end{array}$} & \multicolumn{3}{|c|}{$\begin{array}{c}\text { Grain yield } \\
\text { (tons/ fed) } 2017\end{array}$} & \multicolumn{3}{|c|}{ Milling (\%) 2017} & \multicolumn{3}{|c|}{ Broken (\%) 2017} \\
\hline & 5.70 & & & 70 & 126.80 & & 24.58 & & 2 & & & 3 & 7 & 68 & & 7.97 & 7.81 & 7.90 \\
\hline $20 * 25$ & 301.10 & 315.30 & 313.30 & 20.40 & 116.00 & 115.70 & 1.12 & 25.20 & 25.64 & 3.38 & 3.63 & 3.62 & 0.08 & 70.27 & 70.27 & 8.41 & 8.50 & 8.45 \\
\hline LSD 0.05 & & 12.22 & & & 8.70 & & & 0.49 & & & 0.11 & & & 0.15 & & & 0.14 & \\
\hline
\end{tabular}

Table 7. Mean values for some characters as affected by the interaction between rice cultivars, hill spacing and number of seedlings in 2017 and 2018 seasons

\begin{tabular}{|c|c|c|c|c|c|c|c|c|c|c|c|c|c|c|c|c|}
\hline \multirow{3}{*}{ Cultivars } & \multirow{3}{*}{ No. seedlings } & \multicolumn{6}{|c|}{ No. of panicles / $\mathbf{m}^{2}$} & \multicolumn{6}{|c|}{ Hulling \% } & \multirow{2}{*}{\multicolumn{3}{|c|}{$\begin{array}{c}\text { Broken \% } \\
2018 \\
\end{array}$}} \\
\hline & & & 2017 & & & 2018 & & & 2017 & & & 2018 & & & & \\
\hline & & 2 & 3 & 4 & 2 & 3 & 4 & 2 & 3 & 4 & 2 & 3 & 4 & 2 & 3 & 4 \\
\hline \multirow{3}{*}{ G. 179} & $15 * 20$ & 305.00 & 366.30 & 333.70 & 317.00 & 388.30 & 348.70 & 80.03 & 80.36 & 80.14 & 79.54 & 79.93 & 79.46 & 10.75 & 10.51 & 10.65 \\
\hline & $20 * 20$ & 291.00 & 329.30 & 329.30 & 296.00 & 337.30 & 324.30 & 79.39 & 79.98 & 79.88 & 78.70 & 79.08 & 79.28 & 12.58 & 12.50 & 12.28 \\
\hline & $20 * 25$ & 285.00 & 306.00 & 290.00 & 287.30 & 302.00 & 309.00 & 79.21 & 78.83 & 78.65 & 78.66 & 78.48 & 78.38 & 13.46 & 12.90 & 13.12 \\
\hline \multirow{3}{*}{ S. 106} & $15 * 20$ & 297.00 & 311.30 & 301.00 & 305.30 & 328.30 & 336.70 & 79.55 & 79.68 & 79.61 & 80.01 & 80.54 & 80.45 & 5.88 & 5.73 & 6.53 \\
\hline & $20 * 20$ & 307.30 & 368.30 & 332.70 & 336.70 & 398.30 & 345.00 & 80.18 & 80.47 & 80.31 & 80.53 & 81.41 & 80.73 & 6.00 & 5.65 & 6.15 \\
\hline & $20 * 25$ & 305.00 & 311.70 & 325.30 & 330.00 & 346.70 & 366.70 & 79.91 & 80.14 & 80.08 & 80.50 & 80.62 & 80.44 & 6.15 & 6.22 & 6.26 \\
\hline \multirow{3}{*}{ G.178 } & $15 * 20$ & 315.00 & 321.70 & 323.00 & 328.30 & 346.70 & 345.00 & 79.14 & 79.15 & 79.34 & 79.45 & 79.85 & 80.01 & 8.48 & 8.70 & 8.16 \\
\hline & $20 * 20$ & 330.70 & 363.30 & 339.00 & 362.00 & 405.00 & 362.00 & 79.40 & 80.15 & 79.75 & 79.65 & 79.65 & 80.01 & 8.35 & 7.58 & 8.08 \\
\hline & $20 * 25$ & 313.30 & 328.30 & 324.70 & 352.00 & 355.00 & 356.70 & 79.60 & 79.62 & 79.66 & 79.76 & 79.26 & 79.33 & 8.67 & 8.16 & 8.28 \\
\hline \multicolumn{2}{|c|}{ LSD 0.05} & & 22.82 & & & 24.87 & & & 0.33 & & & 0.35 & & & 0.35 & \\
\hline
\end{tabular}





\section{Interaction between cultivars and number of seedlings/hill:}

Giza 179 and 3 seedlings/hill showed superiority in grain yield (4.21 and $4.50 \mathrm{t} / \mathrm{fed})$ in the first and second seasons, respectively and milling \% (71.02\%) in 2017 only, as shown in table (5). Moreover, Giza 178 and four seedlings/hill interaction showed the highest values for number of filled grains/panicle (126.78) and protein $\%(8.04 \%)$ in 2017 season, only and highest amylose \% (19.60) in 2018 season only.

\section{Interaction between plant spacing and number of seedling/hill:}

Results presented in table (6) showed that transplanting rice at $20 \times 20 \mathrm{~cm}$ plant spacing and three seedlings/hill showed the superiority values for grain yield (4.02 t/fed) and milling \% (70.76 \%) in 2017 only, and highest values for number of filled grains/panicle (134.90) and 1000-grain weight (25.70 gm) in 2018 season only.

\section{Interaction between cultivars, plant spacing and number of seedlings/hill:}

The highest value for number of panicles $/ \mathrm{m}^{2}$ (405) was noticed with Giza 178 rice cultivar with 20 x $20 \mathrm{~cm}$ plant spacing and 3 seedlings /hill in 2018 season only. Moreover, Sakha 106 rice cultivar with $20 \times 20 \mathrm{~cm}$ plant spacing and three seedlings/hill showed superiority for hulling \% (80.47 and $81.41 \%)$ in both seasons, respectively while, superiority for number of panicles $/ \mathrm{m}^{2}$ (368.3) in 2017 season only. Furthermore, the highest broken \% (13.46\%) was detected with Giza 179 rice cultivar, $20 \times 25 \mathrm{~cm}$ plant spacing and three seedlings /hill in 2018 season, only (table 7).

\section{REFRERENCES}

Abd El Salam, R.M. 2003. Effect of some cultural treatments on rice yield and its components. M.Sc. Thesis, Fac. of Agric.,Agron. Dept., Cairo Univ., Egypt.

Abd-El Salam K.M.H, M. A.E.El-Dalil and E. K.E.Abd El Ghany. 2016. Mean performance and genetic variability of some grain quality characteristics of rice (Oryza Sativa L.). Alex. Sci. Exch. J. 37 (1): 76-84.

Abdel-Salam, K.M.H. 2006. Effect of some agricultural practices on yield and grain quality of rice in newly reclaimed soils. M.Sc. Thesis, Fac. Agric. (Saba Basha), Alexandria Univ. Egypt.

Dass A., S.Chandra, A.K.Choudhary, G. Singh and S. Sudhishri. 2016. Influence of field responding pattern and plant spacing on rice root-shoot characteristics, yield, and water productivity of two modern cultivars under SRI management in Indian Mollisols. Paddy water Environ. 14: 45-59.

Depar,N.,I. Rajpar,M.Y. Memon,M. Imtiaz and Zia-ulHassan. 2011. Mineral nutrient densities in some domestic and exotic rice genotypes. Pak. J. Agri. Agril.Eng. vet. Sci. 27: $134-142$.

El Shayeb, Omnia.M. 2003. Effect of hill spacing, nitrogen levels and harvest date on rice productivity and grain quality. M.Sc. Thesis, Fac. of Agric., Agron. Dept., Mansoura Univ. Egypt.

El-Nory, M.I. (2008). Effect of organic and nitrogen fertilizer on the performance of some rice cultivars under North Delta conditions. M.Sc. Thesis Fac. of Agric. Kafr ElSheikh, Univ., Egypt.

El-Sherif, E., S.A. Ghanem, R. Sorour and A. Abdou Zadan. 2007. Rice production under organic and inorganic fertilization. J. Agric. Sci. Mansoura Univ. 32 (3): 16111626.

Gomez, K.A. and A.A. Gomez. 1984. Statistical Procedures for Agricultural Research. An International Rice Research Institute Book. John Willey and Sons Inc., New York, U.S.A.

Gorgy, R.N. 2007. Performance of hybrid and inbred rice cultivars under different planting geometry and number of seedlings per hill. J. Agric. Sci. Mansoura Univ. 32(1): 117-131.

Hasanuzzaman, M., K. Nahar, T.S. Roy, M.L. Rahman, M.Z. Hossain and J.U. Ahmed. 2009. Tiller dynamics and dry matter production of transplanted rice as affected by plant spacing and number of seedling per hill. Acad. J. of Plant Sci., 2 (3): 162-168.

Hossain, M. S., Singh, A.K. and Fasih-uz-Zaman. 2009. Cooking and eating characteristics of some newly identified inter sub-specific (indica/japonica) rice hybrids. Sci. Asia. 35: 320-325.

International Rice Research Institute (IRRI) .1996.. Standard Evaluation System for Rice. IRRI, Manila, Philippines. Pp. 52.

Kengo, I. and M. Kitano.2005. Effect of number of seedlings per hill on rice tillering. Jap. J. Crop Sci. 74 (2): 141-148.

Liming, Z., L.Ming, Z.Dianfeng, G.Chunmei, N.Yongguanng and X.Baosheny.2015. Effects of irrigation methods and rice planting densities on yield and photosynthetic characteristics of matter production in cold area. Transactions of the Chinese Soci. of Agricu. Engineer. 31 (6): 159-169.

Maclean J.L.; D.C. Dawe; B. Hardy and CL. Hettel. 2002. Rice Almanac. Los Ban'os (Philippines): International Rice Research Institute, Bouake (Co'te d'lvoire): West Africa, Rice Development Association, Cali (Colombia): International Center for, Rome Tropical Agriculture (Italy): Food and Agriculture Organization, p 253.

Radwan, F.I., I. Abou- El- Seoud and A. Badr. 2008. Response of two rice cultivars to blue grain green Algae, A mycorrhizae inoculation and mineral nitrogen fertilizer. J. of Plant Sci. and Biotechnology. 2 (1): 29-34.

Rafii, M.Y., M.Z. Zakiah, R. Asfaliza, M.D. Iffah Haifaa, M.A. Latif and M.A. Malek .2014.Grain quality performance and heritability estimation in selected $\mathrm{F} 1$ rice genotypes Sains Malaysiana.43(1) : 1-7. 
Rebeira, S.P., H.A.M. Wickramasinghe, W.L.G. Samarasinghe, and B.D.R. Prashantha. 2014. Diversity of grain quality characteristics of traditional rice (OryzaSativa L.) varieties in Sri Lanka.Tropi. Agric. Res. 25 (4): 570-578.
SAS Institute. 1999. SAS Systems. Version 8. Statistical Analysis System Institute, Cary, NC, USA.

Shaalan, A.M.A. 2009. Studies on some factors affecting quality characteristics in rice crop.Ph.D. Thesis, Fac. of Agric. Alex. Univ. Egypt. 


\section{الملخص العربي}

تأثير مسافات الشتل وعدد البادرات فى الجورة على المحصول ومكوناته ويعض صفات الجودة لحبوب بعض الأصناف الأرز المصرية

دعاء أحمد أنور عبد البارى، خالد مصطفى حمدى عبد السلام، أحمد محجوب شعلان الاصنياف

أجريت تجربتان حقلتين فى محطة البحوث الزراعية- ونسبة التقشير ونسبة التيض ونسبة البروتين فى كلا

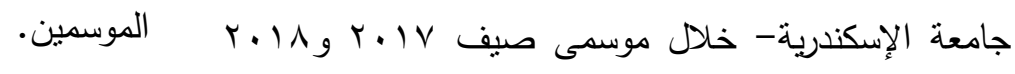

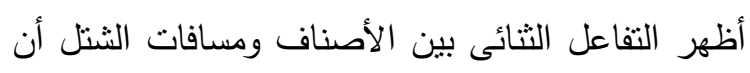

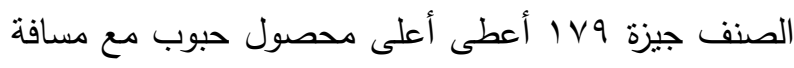

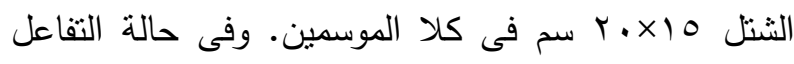

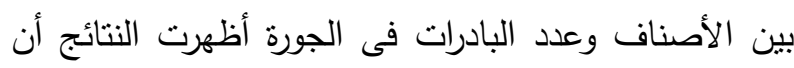

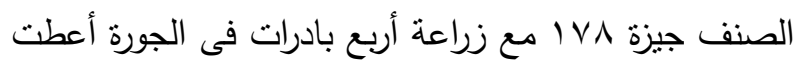

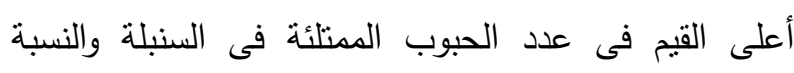
المئوية للبروتين والنسبة المئوية للأكيلوز .

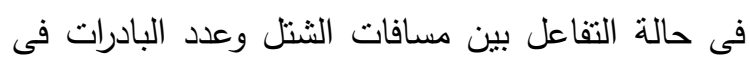

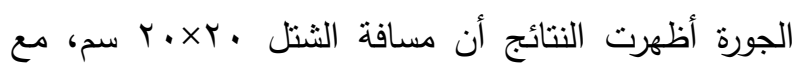
زراعة ثلاث بادرات فى الجورة تفوقت فى صفة محصول

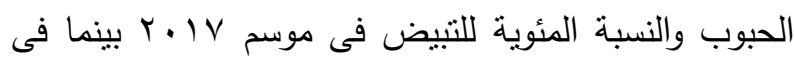

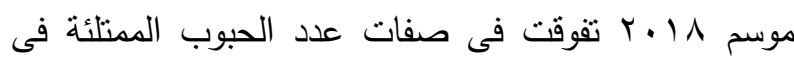
السنبلة ووزن الألف حبة.

من ناحية أخرى أظهر التفاعل بين العوامل الثلاثة تحت الأه

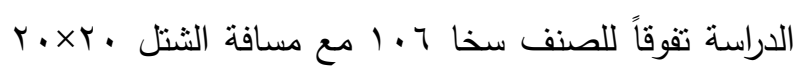

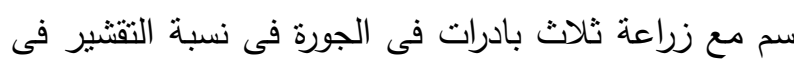

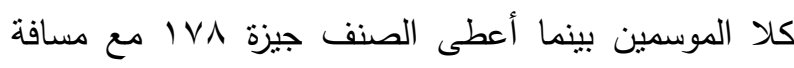

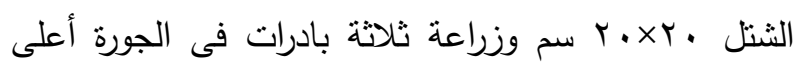
عدد من السنابل فى ربع منز المربع.

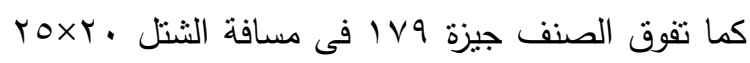
سم مع زراعة ب-؟ بادرات فى الجورة لصفة النسبة المئوية للكسر فى الحبوب. رئ.

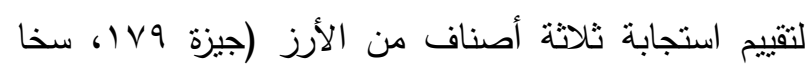

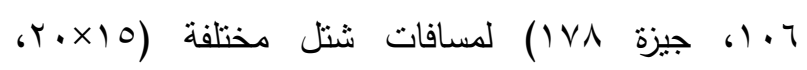

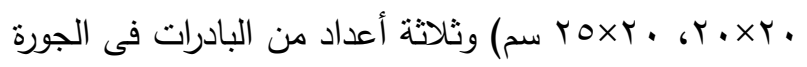

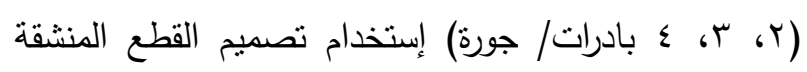
مرتين بثلاث مكررات فى كلا الموسمين.

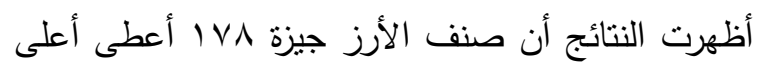

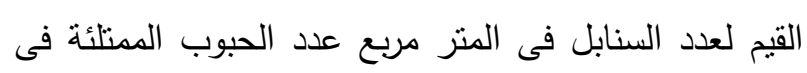

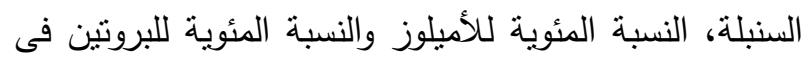

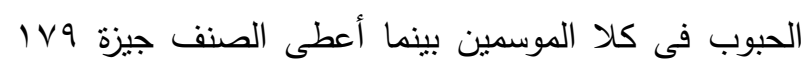

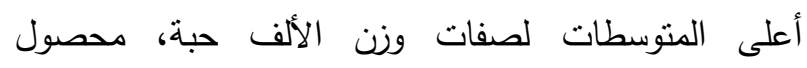
الحبوب، والنسبة المئوية للكسر فى كلا الموسمين.

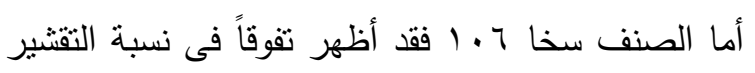
والنسبة المئوية للتبيض فى كلا الموسمين. أعلى القيم لصفات عدد السنابل فى المتز المربع، عدد الصئه الحبوب الممتلئة فى السنبلة، محصول الحبوب، النسبة المئوية للتقتير والنسبة المئوية للتبيض والنسبة المئوية

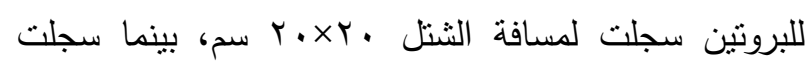

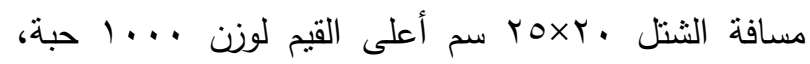
النسبة المئوية للكسر والنسبة المئوية للأميلوز وذلك في كلا للان

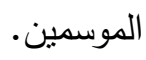

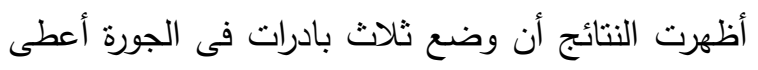

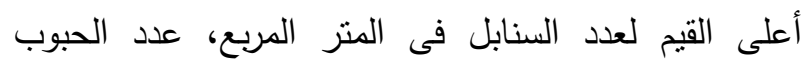

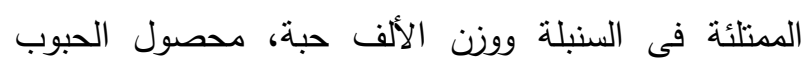

